\title{
MODEL ZARZĄDZANIA JAKOŚCIĄ USLUG W KONTEKŚCIE SATYSFAKCJI KLIENTA
}

\begin{abstract}
Streszczenie: Podstawowym celem artykułu jest przedstawienie propozycji modelu zarządzania jakością usług w kontekście satysfakcji klienta. Pierwsza część opracowania zawiera teorię z zakresu zarządzania jakością usług oraz znaczenia satysfakcji klienta. Następnie, przedstawione zostały wyniki badań empirycznych nad satysfakcją klienta. Ostatnia część artykułu to propozycja modelu zarządzania jakością usług w kontekście satysfakcji klienta.
\end{abstract}

Słowa kluczowe: jakość usług, model zarządzania jakością, satysfakcja klienta, zarządzanie jakością usług

\section{Wprowadzenie}

Współczesne przedsiębiorstwa usługowe funkcjonują w dynamicznym, wysoce konkurencyjnym otoczeniu. Poszukiwanie i korzystanie $\mathrm{z}$ wielu nowoczesnych i różnorodnych narzędzi walki konkurencyjnej stanowi podstawę umożliwienia przedsiębiorstwu stabilnego funkcjonowania i rozwoju w złożonym środowisku [1].

Przekonanie klienta o wyjątkowości i dominacji usług danego podmiotu gospodarczego nie powiedzie się bez solidnych fundamentów. Zaawansowany marketing, międzynarodowa współpraca oraz solidne zaplecze finansowe i bogate uwarunkowania techniczne przedsiębiorstwa nie przyniosą efektu bez czynnika, który w największym stopniu wpływa na decyzje klientów - samej usługi. Wobec tego, za początek działań rozwojowych należy przyjąć zaprojektowanie usługi spełniającej wymagania klientów i posiadającej zestaw cech przez nich pożądanych [2].

Jednym z nich jest wysoka jakość usług. Zagadnienia dotyczące jakości stanowią obszerny zbiór opracowań w literaturze przedmiotu.

Pierwotne definicje jakości powstały na bazie jej postrzegania przez Platona, który twierdził, iż jakość to osiągnięty stopień doskonałości, oceniany subiektywnie poprzez doświadczenie. Zainteresowanie filozofów terminem jakości poskutkowało

1 Mgr inż., Członek Koła Naukowego „Promotor Jakości”, Wydział Zarządzania, Politechnika Częstochowska, Al. Armii Krajowej 19b, 42-200 Częstochowa, Polska, e-mali: kamilakowalik93@gmail.com

2 Dr inż., Katedra Inżynierii Produkcji i Bezpieczeństwa, Wydział Zarządzania, Politechnika Częstochowska, Al. Armii Krajowej 19b, 42-200 Częstochowa, Polska, e-mail: dorota.klimeckatatar@wz.pcz.pl 
odrębnymi charakterystykami Arystotelesa i Cycerona (jakość jako determinanta rzeczy) Kartezjusza (jakość pierwotna - jakość przedmiotu i jakość wtórna - jakość jaką tworzy jego użytkowanie) czy Kanta (zbiór cech rzeczywistości postrzeganej subiektywnie) [3].

Różne podejścia filozofów przyczyniły się do wyszczególnienia różnych rodzajów jakości w aspekcie określonych kryteriów, których badaniem naukowcy zajmują się od wielu lat. Opracowania współczesne wyróżniają jakość głównie pod względem technicznym (jakość jako zgodność wyboru $\mathrm{z}$ normą, standardem, projektem; jakość jako zestaw cech fizycznych, chemicznych i biologicznych dobra lub usługi, jakość jako właściwości określające stopień przydatności do użytkowania), ekonomicznym (jakość jako poziom spełnienia wymagań) oraz ujęcie marketingowe (jakość jako usatysfakcjonowanie klienta) [4,5].

\section{Zarządzanie jakością usług}

Zarządzanie zdefiniować można jako zestaw działań, wśród których wyróżnia się planowanie, organizowanie, przewodzenie, kontrolę oraz motywowanie, oddziałujących na zasoby rzeczowe, ludzkie, finansowe i informacyjne w celu zapewnienia efektywnego funkcjonowania organizacji [6].

Koncepcja zarządzania jakością rozwijała się na przestrzeni lat. Rozwój ten, wciąż kontynuowany, został zapoczątkowany na początku XX wieku w ramach rozpoczęcia tak zwanej ,inspekcji jakości', Wtedy to wyszkoleni inspektorzy rozpoczęli kontrole jakości wyrobów gotowych. Zagadnienia kontroli zostały rozbudowane dzięki Walterowi Shewhart'owi, który w 1924 wprowadził karty kontrolne, inicjując $\mathrm{w}$ ten sposób kontrolę jakości przeprowadzaną $\mathrm{w}$ trakcie procesu produkcyjnego, w którą angażowano wszystkich pracowników. W połowie stulecia opracowane zostało zagadnienie ,zapewnienia jakości”, jako wynik rozwoju i modyfikacji metod kontroli procesu i wyrobów gotowych, w które włączono także planowanie, regulację i symulację jakości. Na tych fundamentach, od roku około 1980, mamy do czynienia z zarządzaniem jakością, obejmującym funkcje planowania, zapewnienia, sterowania i doskonalenia jakości jako narzędzia walki konkurencyjnej i filozofii funkcjonowania przedsiębiorstwa (rys.1) [7].

Doskonalenie w ramach zarządzania jakością wywodzi się z filozofii Kaizen, która za podstawę praktyki biznesu przyjmuje ciągłe doskonalenie, czyli regularne i stopniowe wprowadzanie zmian (o charakterze trwałym) we wszystkich procesach, których celem jest nieustanne podnoszenie jakości poprzez zwiększenie efektywności i wydajności funkcjonowania (zwiększenie zysków przy zmniejszeniu kosztów) [9]. 


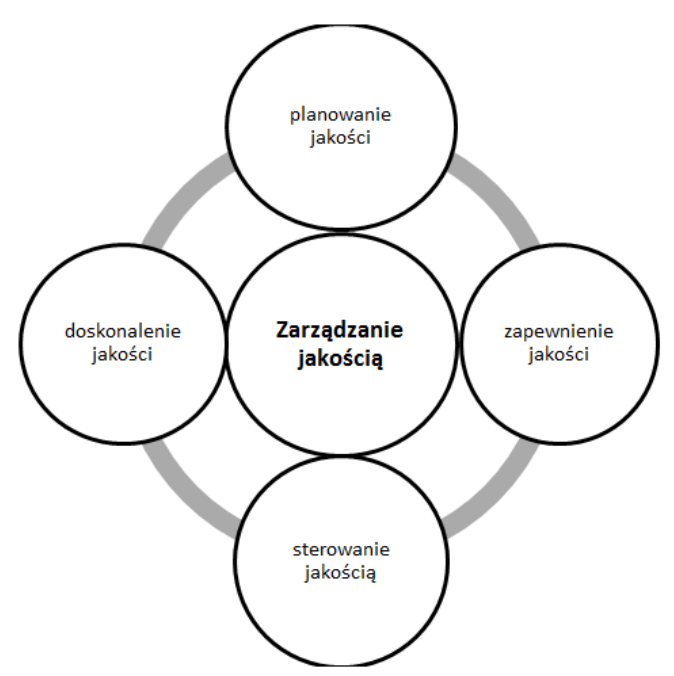

\section{Rys. 1. Zarządzanie jakościa}

Źródto: Opracowanie własne na podstawie [8]

Przedstawione ogólne założenia zarządzania jakością odnoszą się zarówno do jakości produkcji, jak i jakości usług. Jakość usług jednak zasadniczo rożni się od jakości wyrobów przemysłowych. Wśród jej podstawowych aspektów wyróżnia się [10]:

- trudność w określeniu standardów jakościowych,

- trudność obiektywnego pomiaru (różnorodność subiektywnych kryteriów, dobór wymiernych wskaźników),

- brak podziału odpowiedzialności za jakość (jakość warunkowana przez usługodawcę),

- identyfikacja interakcji między usługodawcą i usługobiorcą, który często aktywnie uczestniczy w procesie świadczenia usługi,

- problematyka planowania (brak możliwości magazynowania),

- brak tolerancji błędów w świadczeniu usługi,

- satysfakcja klienta jako funkcja spełnienia indywidualnych oczekiwań.

\section{Satysfakcja klienta}

Satysfakcja klienta uznawana jest za szczególną determinantę jakości usług. Często bywa w literaturze określana mianem „odpowiedzi na dobrą lub złą jakość produktu lub usługi’”.

Różne podejścia do interpretacji terminu ,satysfakcja” przyczyniły się do powstania wielu różnych jej definicji. Najogólniejsze z nich wskazują na emocjonalne 
podejście do usługi oraz odnoszenie potrzeb i oczekiwań klienta, a także wcześniejszych doświadczeń, do odbierania świadczonej usługi [11].

Techniczne podejście do charakteryzowania tego pojęcia obejmuje także zależność satysfakcji od użyteczności i subiektywnych właściwości usługi.

Warto dodać, iż współczesne opracowania teoretyczne z zakresu satysfakcji często bazują na postrzeganiu T. Levitta i jego definicji z 1960 roku opartej na przekonaniu o konieczności dostosowania przemysłu do zadowolenia klienta [12].

Złożona natura satysfakcji wyróżnia oddziaływanie przedsiębiorstwa na sferę poznawczą i emocjonalną. Kwestia emocji coraz częściej znajduje swoje zastosowanie w charakteryzowaniu i badaniach satysfakcji, która w tym ujęciu stanowi pozytywne uczucia, jakich klient doznaje dzięki zaspokojeniu potrzeb i spełnieniu jego oczekiwań.

Źródłem tych odczuć jest wartość, jaką dla klienta stanowi rezultat procesu usługowego. Należy wskazać, iż odczucie może pojawić się bezpośrednio po zakończeniu procesu świadczenia usługi, ale także jako reakcja na całokształt doświadczeń związanych ze skorzystaniem $\mathrm{z}$ oferty usługowej danego przedsiębiorstwa.

Pozytywne odczucia klienta, czyli odczuwanie satysfakcji, pojawiają się w przypadku spełnienia jego potrzeb i oczekiwań. Jeśli wymagania te nie zostaną zaspokojone, identyfikowane są odczucia negatywne, skutkujące brakiem satysfakcji i niezadowoleniem [13].

Wysoka jakość usługi, postrzegana jako główna determinanta satysfakcji, nie jest jedynym czynnikiem ją budującą. Klient poziom zadowolenia kształtuje również $\mathrm{w}$ oparciu o czynniki sytuacyjne (takie jak samopoczucie) oraz aspekty wewnętrznych potrzeb, norm, standardów i oczekiwań [14].

Rozwój metodologii badań z zakresu satysfakcji przyczynił się do opracowania modelu przedstawiającego mechanizm kształtowania się satysfakcji (rys. 2).

W modelu tym satysfakcja to wynik uświadomionej jakości i wartości, jaką klient uważa, że uzyskał, ocenionej poprzez porównanie z wcześniej określonymi wymaganiami. 


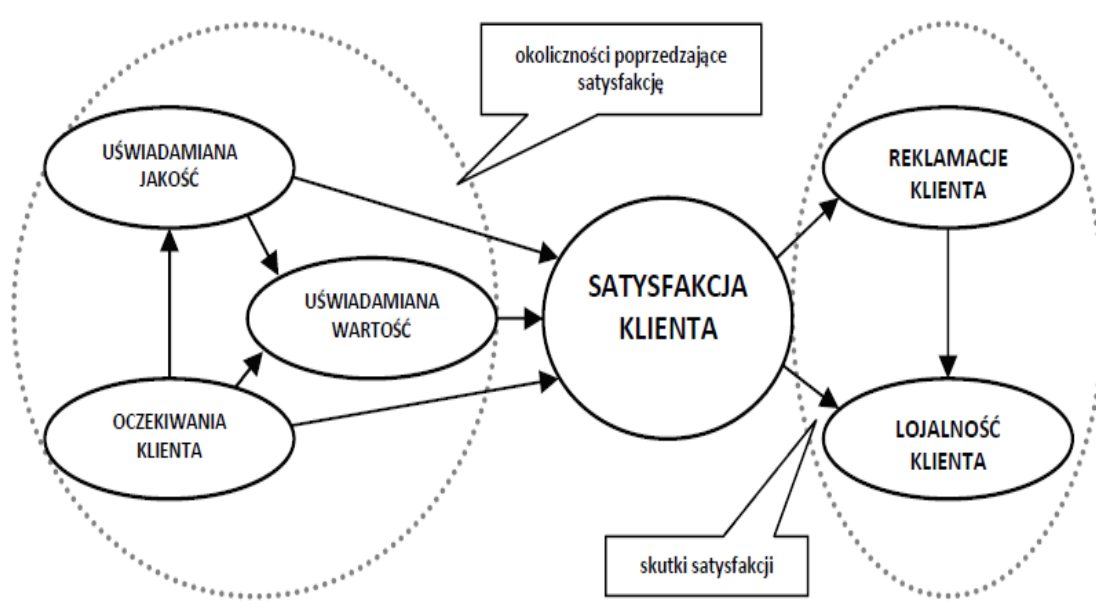

Rys. 2. Mechanizm powstawania satysfakcji klienta

Źródto: Opracowanie własne na podstawie [15]

Skutki satysfakcji mogą wymieć wymiar pozytywny (lojalność klienta) oraz negatywne (reklamacje klienta).

Podsumowanie rozważań nad satysfakcją pozwalają definiować ją jako wypadkową wymagań klienta (określanych przez procesem świadczenia usługi) i doświadczeń (pojawiających się po wyświadczeniu usługi) [16].

\section{Wyniki przeprowadzonych badań - model zarządzania jakością w kontekście satysfakcji klienta}

W oparciu o przeprowadzone badania literaturowe nad zagadnieniami zarządzania jakością usług i satysfakcją klienta, których celem jest budowa modelu zarządzania jakością usług $\mathrm{w}$ jej kontekście, opracowany został arkusz anonimowej ankiety przeznaczonej dla klientów przedsiębiorstw usługowych. Celem ankiety było uzyskanie potwierdzenia umieszczenia poszczególnych aspektów zarządzania jakością (jako czynników kształtujących satysfakcję) w modelu wraz z przesłankami wynikającymi z literatury przedmiotu.

Dla potrzeb badań, wymagających wskazania poziomu istotności poszczególnych funkcji zarządzania jakością, zastosowano twierdzenia poddane przez respondentów ocenie $\mathrm{z}$ wykorzystaniem skali Likerta. Ankietowani mieli do dyspozycji skalę 1-5, gdzie 1 oznacza ,zdecydowanie się nie zgadzam”, a 5 - ,zdecydowanie się zgadzam".

Ankieta została przeprowadzona $w$ dniach 30.05-1.06. 2018 drogą elektroniczną za pośrednictwem Internetu. Uczestniczyło w niej 100 respondentów obu płci w wieku 18-65 lat. Struktura grupy badanej zawarta jest w tabeli 1. 
Tabela 1. Struktura respondentów

\begin{tabular}{|c|c|c|c|}
\hline Wiek & Mężczyźni, \% & Kobiety, \% & Razem, \% \\
\hline $18-24$ & 10 & 24 & 34 \\
\hline $25-39$ & 18 & 19 & 37 \\
\hline $40-59$ & 14 & 8 & 22 \\
\hline $60<$ & 2 & 5 & 7 \\
\hline \multicolumn{3}{|r}{} & $\mathbf{1 0 0}$ \\
\cline { 3 - 4 }
\end{tabular}

Pierwsze, ogólne stwierdzenie dotyczy wpływu jakości na satysfakcję klienta z usługi (jakość usługi stanowi główną determinantę satysfakcji) (rys. 3).

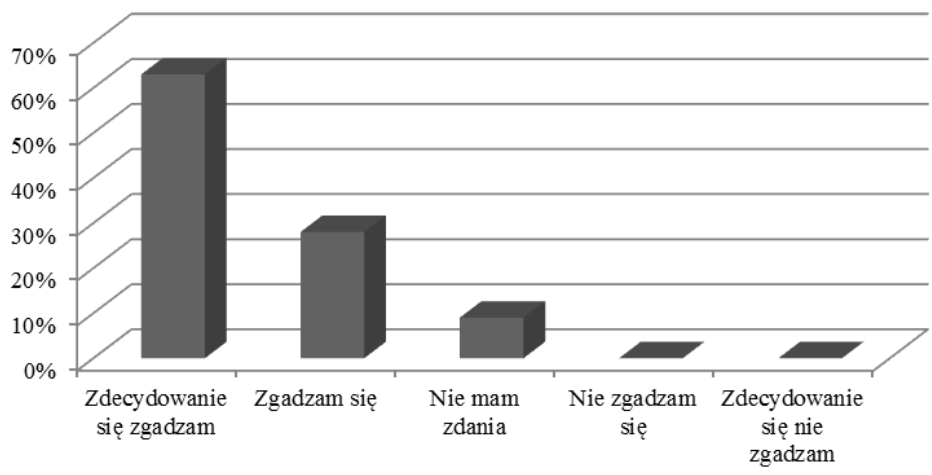

Rys. 3. Jakość ustugi jako glówna determinanta satysfakcji-opinia respondentów

Przedstawione dane wskazują na szczególne znaczenie jakości jako głównego czynnika kształtującego satysfakcję. Z powyższym stwierdzeniem zdecydowanie zgadza się $63 \%$ respondentów, $28 \%$ z nich się zgadza a $9 \%$ nie ma własnej opinii na ten temat. Warto zauważyć, iż żaden respondent nie zaprzeczył istotności jakości w kształtowaniu satysfakcji klienta. Informacje te stanowią potwierdzenie słuszności budowy modelu zarządzania jakością w aspekcie satysfakcji klienta.

Kolejne twierdzenie z ankiety brzmi „Klient osiąga satysfakcję z usługi jeśli jej jakość jest dokładnie zaplanowana’. Wyniki zawarte zostały na rysunku 4. 


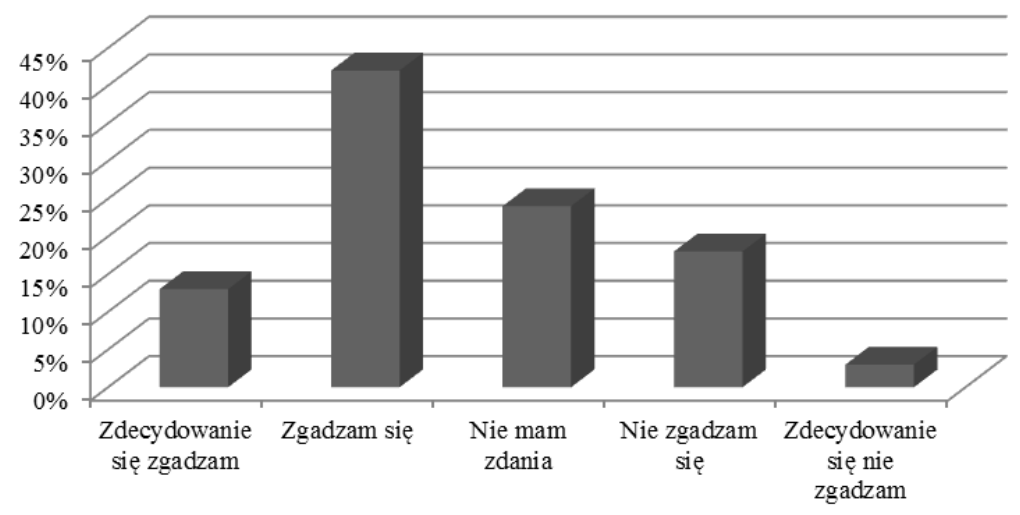

Rys. 4. Planowanie jakości jako determinanta satysfakcji klienta-opinia respondentów

$\mathrm{Z}$ rysunku wynika, iż planowanie jakości usługi oddziałuje na satysfakcję klienta. $Z$ twierdzeniem tym zdecydowanie zgadza się $13 \%$ ankietowanych, a prawie połowa (42\% z nich) się z nim zgadza. Aż $24 \%$ respondentów nie ma własnej opinii na ten temat (co może wynikać $\mathrm{z}$ braku rozważań nad analizowanym zagadnieniem), a łącznie $21 \%$ z nich nie zgadza się (18\%) lub zdecydowanie nie uważa tego stwierdzenia za prawdę (3\%). Dane te pozwalają uważać, iż klienci oczekują usługi o zaplanowanej jakości, czyli jakość usługi stanowić musi wynik prac nad jej osiągnięciem, a nie być rezultatem przypadku.

Zamierzeniem kolejnego pytania zawartego w ankiecie było poznanie opinii respondentów na temat postrzegania przez nich znaczenia zarządzania jakością w kształtowaniu satysfakcji klienta (rys. 5).

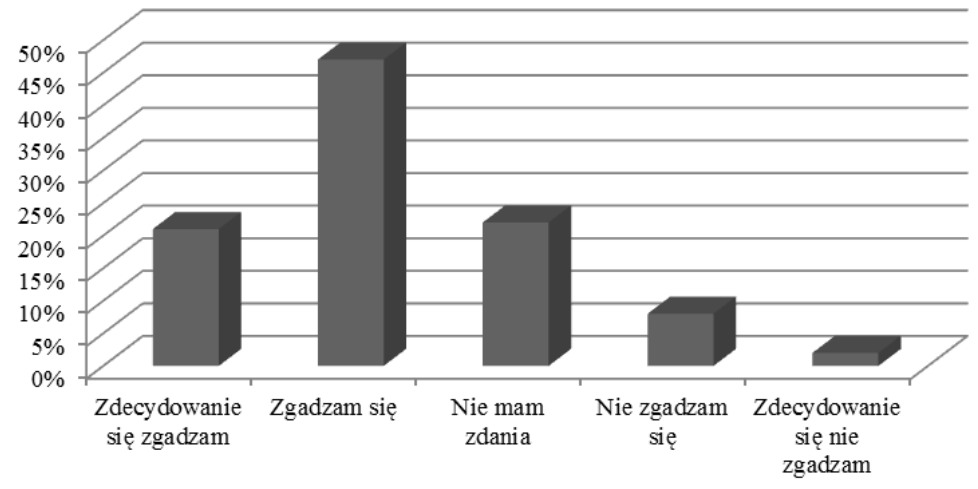

Rys. 5. Zarządzanie jakością jako determinanta satysfakcji klienta - opinia respondentów 
Uzyskane dane wskazują na nieco większe znaczenie zarządzania jakością w kształtowaniu satysfakcji klienta. Łącznie 68\% respondentów zdecydowanie się zgadza (21\%) lub zgadza się (47\%) z powyższym stwierdzeniem (różnica o $13 \%$ ). Nieco mniej ankietowanych niż w pytaniu poprzednim (22\%) nie ma zdania na ten temat, również mniej z nich (10\%) nie zgadza się (8\%) lub zdecydowanie nie zgadza się (3\%) z prawdziwością tego założenia. Nie znaczy to, że planowanie jakości nie ma wpływu na satysfakcję klienta, ale iż zarządzanie nią postrzegają oni jako ważniejsze.

Kolejne pytanie obejmuje oddziaływanie kontroli jakości na kształtowanie satysfakcji klienta (rys. 6).

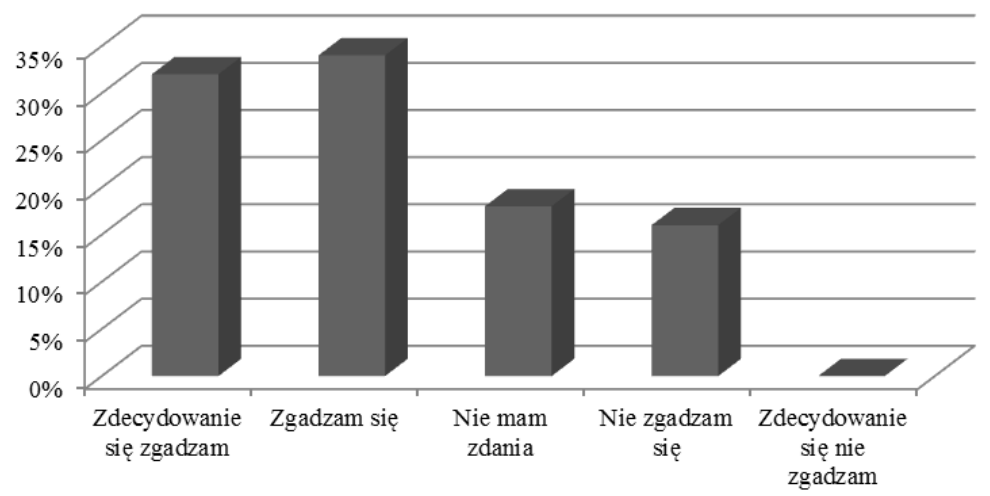

Rys. 6. Kontrola jakości jako determinanta satysfakcji klienta - opinia respondentów

Przedstawione dane znacznie różnią się od wyników uzyskanych w poprzednich pytaniach. Przede wszystkim wzrosła liczba respondentów, którzy postrzegają kontrolę jakości usług jako istotną determinantę kształtującą satysfakcję klienta. $\mathrm{Z}$ tym twierdzeniem zdecydowanie zgadza się $32 \% \mathrm{z}$ nich, a $34 \%$ się z nim zgadza. Prawie co piąty ankietowany (18\%) nie ma zdania na ten temat, a $16 \%$ respondentów nie identyfikuje powiązania kontroli jakości usług z ich satysfakcją.

Zamierzeniem ostatniego pytania było pozyskanie informacji odnośnie oddziaływania działań doskonalących podejmowanych przez przedsiębiorstwo usługowe na satysfakcję klientów z usług (rys. 7).

Poziom odpowiedzi respondentów zgadzających się z tym stwierdzeniem jest w ramach tego pytania najwyższy w badaniu. Prawie połowa ankietowanych (46\%) zdecydowanie się z nim zgadza, a aż $38 \%$ się zgadza. Co dziesiąty respondent (12\%) nie ma zdania na ten temat, a jedynie $4 \%$ nie identyfikuje zależności. 


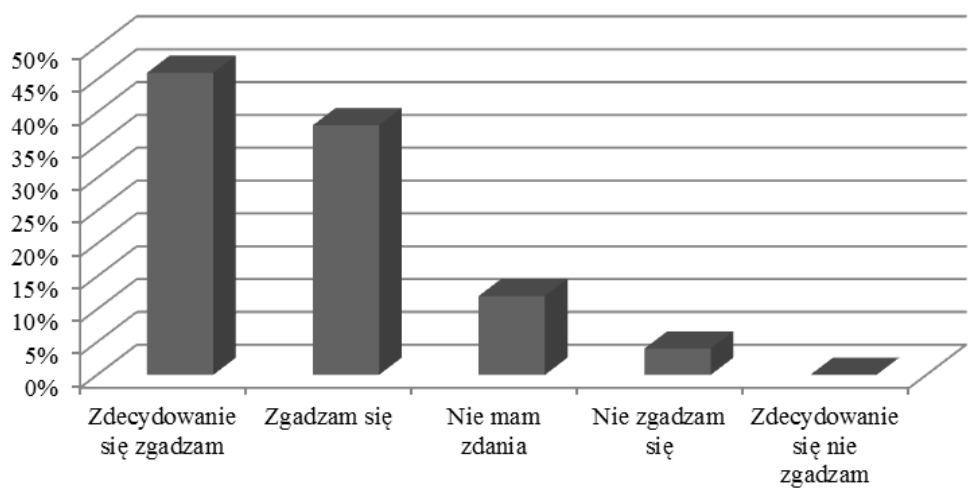

\section{Rys. 7. Kontrola jakości jako determinanta satysfakcji klienta - opinia respondentów}

Podstawowym wnioskiem uzyskanym $\mathrm{w}$ wyniku badania ankietowego jest potwierdzenie dużego wpływu jakości na kształtowanie satysfakcji klienta z usługi. Ponadto, satysfakcja klientów, jako zagadnienie złożone, powstaje w oparciu o szereg powiązanych ze sobą czynników. Respondenci potwierdzili, iż aspekty jakości, w ramach których wyróżnić można planowanie jakości, zarządzanie jakością, kontrolę jakości i doskonalenie jakości zawierają się w kręgu determinantów satysfakcji.

Na podstawie badań literaturowych i empirycznych opracowany został model zarządzania jakością w aspekcie satysfakcji klienta (rys. 8).
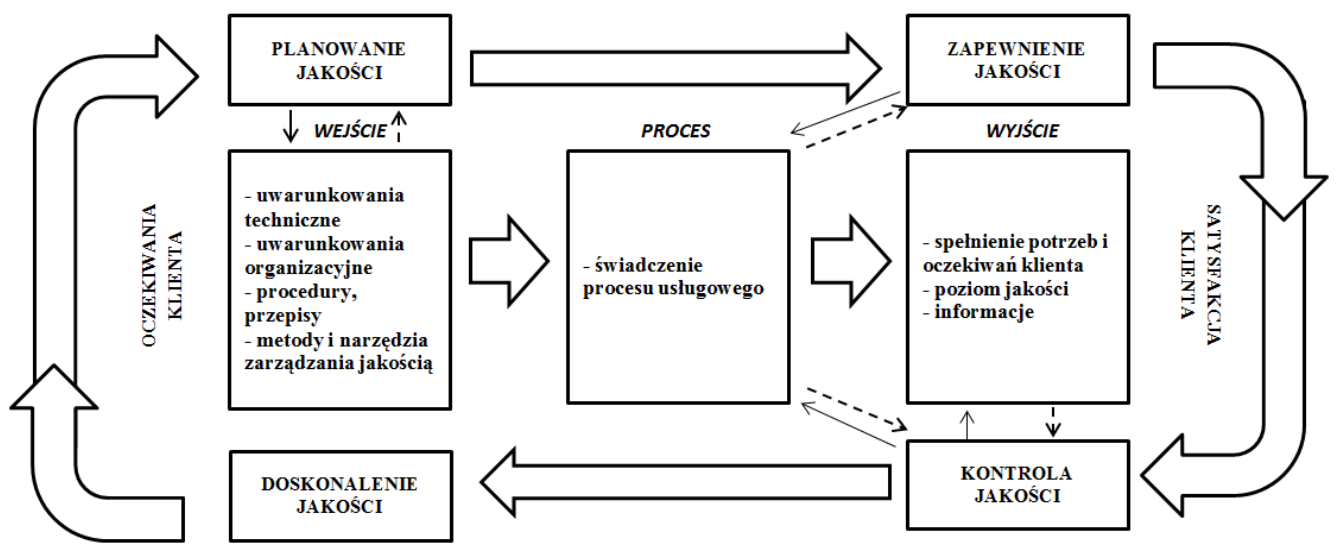

Rys. 8. Model zarządzania jakością usług w kontekście satysfakcji klienta 
Podstawą modelu było procesowe ujęcie usługi, która posiada wektor wejścia (uwarunkowania techniczne i organizacyjne, procedury, przepisy i zasady oraz metody i narzędzia zarządzania jakością), proces przetwarzania (czyli proces świadczenia usługi) oraz wektor wyjścia (spełnienie potrzeb i oczekiwań klienta, poziom jakości oraz informacje). Na wejściu zarządzania znajdują się oczekiwania klienta, a rezultatem procesu zarządzania jest satysfakcja klienta.

Zarządzanie jakością obejmuje procesy takie jak: planowanie jakości na wejściu, zapewnienie jakości procesu oraz kontrolę jakości w trakcie i po świadczeniu usługi. Model dopełnia wymagane doskonalenie jakości, a wszystkie przedstawione procesy tworzą nieustający cykl, w ramach którego doskonalenie ma wpływ na planowanie kolejnej usługi.

\section{Podsumowanie}

Satysfakcja klienta jest zagadnieniem wartym uwagi dla współczesnych przedsiębiorstw usługowych. Coraz bardziej świadomi klienci mają coraz wyższe wymagania odnośnie poszczególnych aspektów usługi. Zadaniem przedsiębiorstwa jest ich identyfikacja i spełnienie. Tylko spełnienie potrzeb, oczekiwań i wymagań klientów przekłada się na osiągnięcie przez nich satysfakcji, co ma bezpośredni wpływ na funkcjonowanie przedsiębiorstwa na dynamicznym rynku wysokiej konkurencyjności.

Jakość stanowi istotną determinantę satysfakcji. Sama w sobie jest również narzędziem walki konkurencyjnej. Zarządzanie jakością powinno być procesem rzetelnie zaplanowanym i regularnie doskonalonym. Przedstawiony model stanowić może podstawę do dalszych badań nad satysfakcją klienta i ukierunkowanym zarządzaniem jakością.

\section{Bibliografia}

[1] Kowalik K., Klimecka-Tatar D. Brozova S. "Service quality model based on the 4Q's model and the system approach to service quality", in Proceedings of the 2nd International Conference: Contemporary Issues in Theory and Practice of Management, 2018, pp. 236-243.

[2] Kang G. James J., "Service quality dimensions: an examination of Grönross's service quality model' Managing Service Quality, vol. 14. no 4, pp. 266-277, 2004.

[3] Horbaczewski D., "Filozoficzne źródła współczesnego pojmowania jakości", Problemy jakości, vol. 10, pp. 9-12, Oct 2006.

[4] Jain P. Aggarval V., "Service quality models: a review" BVIMSR's Journal of Management Research, vol. 7, no 2, pp. 125-136, Oct. 2015.

[5] Rogoziński K., Nowy marketing ustug. AE w Poznaniu: Poznań. 2005, pp. 56-61.

[6] Dahlgaard J., Kristenten K., Kanji G., . Podstawy zarzqdzania jakościa, PWN: Warszawa, 2004, pp. 35-38. 
[7] Hamrol A., Mantura W., Zarzadzanie jakościa. Teoria i praktyka, PWN: Warszawa, 2002, pp. 45-48.

[8] Sałaciński T., SPC-Statystyczne sterowanie procesami produkcyjnymi. Oficyna Wydawnicza Politechniki Warszawskiej: Warszawa, 2009, pp. 13-16.

[9] Łuczak J., Matuszak-Flejszman A., Metody $i$ techniki zarządzania jakością. Kompendium wiedzy, Quality Progress: Poznań, 2007, pp. 147-51.

[10] Kowalik K., Klimecka-Tatar D., "Wpływ procesu obsługi klienta na kształtowanie funkcjonalnej jakości usług" in Instrumenty doskonalenia w zarzadzaniu, R. Ulewicz, P. Sygut Ed. Częstochowa: SMJiP, 2016, pp. 46-57.

[11] Klementova J., Zavadsky J., Zavadska Z., "The Measurement and Evaluation of the Service Quality through Customers 'Satisfaction" Procedia Economics and Finance, vol. 26, pp. 126-130, Dec. 2015.

[12] Haffer R., "Satysfakcja klienta i jej pomiar" in Marketingowe testowanie produktów, S. Sudoł, J. Szymczak, Ed., PWN, Warszawa, 2000, pp. 43-46.

[13] Borkowski S., Wszendybył E., Jakość i efektywność ustug hotelarskich. PWN: Warszawa, 2007, pp. 112-116.

[14] Penc J., Marketing ustug, PWE: Warszawa, 2005, pp. 82-87.

[15] Śmiatacz K., Badanie satysfakcji klientów na przykładzie rynku telefonii komórkowej w Polsce. Uniwersytet Technologiczno-Przyrodniczy: Bydgoszcz, 2012, pp. 11-13.

[16] Jasiulewicz-Kaczmarek M., Misztal A., Projektowanie $i$ integracja systemów zarządzania projakościowego. Politechnika Poznańska: Poznań, 2014, pp. 50-52.

\title{
SERVICE QUALITY MANAGEMENT MODEL IN THE ASPECT OF CUSTOMER SATISFACTION
}

\begin{abstract}
The objective of the article has been to present the proposition of service quality model in the aspect of customer satisfaction. The first part contains the theoretical framework of service quality management and the meaning of customer satisfaction. Afterwards, the results of empirical research have been presented. According to the research, the proposition of service quality management model in the aspect of customer satisfaction has been presented.
\end{abstract}

Key words: customer satisfaction, service quality, service quality management. service quality model

Data przestania publikacji do Redakcji: 19.05.2018

Data akceptacji publikacji przez Redakcję: 29.06.2018 